\title{
LEARNING STYLE PREFERENCES OF LOGISTICS LEARNERS
}

\author{
K. Lambert \\ Department of Marketing, Logistics and Sport Management \\ Tshwane University of Technology \\ Pretoria, South Africa \\ e-mail: lambertkr@tut.ac.za
}

\section{ABSTRACT}

The VARK model categorises learners as $\mathrm{V}$ (visual), $\mathrm{A}$ (aural), (R) (read/write) and $\mathrm{K}$ (kinaesthetic). The visual, aural, read/write and kinaesthetic (VARK) learning style preference of logistics students has previously not been assessed. For this study the learning style preferences of logistics final year Diploma students from Tshwane University of Technology were therefore determined. Eighty questionnaires were distributed with 78 being received back, (a response rate of $97.5 \%$ ). Of which, two could not be used as they were not completed in full, giving 97.4 per cent of useful questionnaires (76 from 78). The dominant learning preference amongst the Logistics III students was a K (kinaesthetic) learning preference (21 out of 76 , or $27.6 \%$ ), followed by $R$ (read/write) learning preference (15 out of 76 , or $19.7 \%$ ). VARK learning preference was third with 10 of $76(13.2 \%)$. In the study 56.6 per cent of the learners preferred a unimodal learning experience, and 43.4 per cent of the learners preferred multimodal learning styles.

Keywords: learning styles, VARK, logistics, education, learning preferences, kinaesthetic

\section{INTRODUCTION}

Learning is a lifelong process and it is frequently argued that education is key to growth in society: "Education is the most powerful weapon which you can use to change the world" (Mandela n.d.). Different learners approach learning in different ways. Kolb and Kolb (2010, 44) define learning as "the process whereby knowledge is created through the transformation of experience". In adult education, learners at colleges and universities develop study skills and acquire relevant learning methods to adjust their learning to the lesson and tutoring styles used by their lecturers; however not all students do this (Hallin 2014). No two students are the same. This applies to lecturers who may have a specific preference in teaching style too.

According to Khurshid $(2015,276)$ no learning styles (LS) exist in isolation, but they all "co-exist with each other" and are widely classified as intuition and sensing, which are opposite mental functions of perceiving as classified by Jung (1971) in his book Psychological Types (1971).

Lesmes-Anel et al. (2001), Felder and Brent (2005), Lujan and DiCarlo (2006), Vorhaus (2010), James, D’Amore and Thomas (2011) (as quoted by Alkhasawneh 2013) have identified 
four areas that may influence a person's LS: (1) emotionality: persistence, structures (internally or externally imposed), responsibility (conformity/non-conformity) and motivation; (2) physiological characteristics: perceptual strengths; (3) immediate environment: furnitureseating designs, temperature, light, and sound; (4) sociological preferences: variety versus routine, working in a pair, working alone, working as part of a team, small group working, and working with either a collegial or an authoritative adult

In the past ten years there has been a concentration on student focused learning environments in undergraduate education (Goldsworthy et al. 2012; Herrington and Herrington 2006, as quoted in Ackland-Tilbrook and Warland 2015). In student focused learning the responsibility for their own learning is driven by the student (Taekman and Shelley 2010 as quoted in Ackland-Tilbrook and Warland 2015). According to Fleming and Mills $(1992,137)$ "... the literature from both psychology and education has supported the proposition that learners of all ages have different yet consistent ways of responding in learning situations".

By matching teaching strategies to LS preferences, academic success is promoted and enhances student engagement (Chang 2006; 2005; Dunn and Griggs 2000; Miller 2001; StittGohdes 2003; as quoted in Cekiso 2011). Research has shown a link between academic performance and LS at university level (Bailey, Onwuegbuzie and Daley 2000; Moeinikia and Zahed-Babelan 2010; Orhun 2012; Rasool and Rawaf 2008; Williams et al. 2013; as quoted in Gohar and Sadeghi 2015).

There are various definitions of LS. Stewart and Felicetti (1992) define LS “... as those educational conditions under which a student is most likely to learn" (as quoted in Asiry 2016, 13). According to Drago and Wagner $(2004,1)$ LS refers to "... the differences that exist between individuals in how they best learn". Keefe (1979, as quoted in Truong 2016, 1185) defines LS as "The composite of characteristic cognitive, affective, and physiological factors that serve as relatively stable indicators of how a learner perceives, interacts with, and responds to the learning environment". Othman and Amiruddin $(2010,652)$ define individual LS as a “... style or learning methods used in the process of learning".

It should be noted that "VARK styles are not a measure of personality per se, and preferred learning styles do not necessarily correspond to personal strengths" (Fleming and Baume 2006 as quoted in Gomez-Heras and McCabe 2014, 100). According to Marcy (2001) the VARK model is useful in improving the learning of students. The literature provides information on numerous LS. Coffield, Moseley, Hall and Ecclestone (2004a) identified 71 different models.

Of the many such models, the three most common are David Kolb's, Fleming's VAK/VARK model and Honey and Mumford's (Al Shaikh 2015). Fleming (2001) reports that approximately 21 per cent of the population who have completed the online VARK 
questionnaire have a preference for all four styles or quad style (VARK), 9 per cent have preference for three styles or tri style (VAR, VAK, VRK or ARK), 27 per cent a preference for two styles or bi style (VA, VR, VK, AR, AK or RK) and 41 per cent a preference for one style (V, A, R or K). Assisting our learners in identifying their specific LS preference should build their confidence and they may well become capable of managing their learning (Herod 2004).

\section{LITERATURE REVIEW}

\section{Proponents of LSs}

Lovelace (2005) in her study concluded that responsive instruction, matched to a learner's LS, improves their attitude and achievement levels. Chiou (2008) agrees that LS also influence academic achievement. According to Rinaldi and Gurung (2008), enhancing learning by means of diverse styles can be advantageous to satisfaction and learning outcomes.

Marek (2013) mentions that research has shown that when students' LS are utilised to form their study behaviour, their confidence increases in their test taking skills and is demonstrated in their metacognition that rises (Noble et al. 2008), increased academic achievement (Chiou 2008), self-efficacy (Shannon 2008) and their method of study (MeehanAndrews 2009; Hardigan and Cohen 2003). In addition, there are different ways to teach, and catering for the different needs of students can enhance learning (Fleming 1995).

According to Sims et al. (1989, as quoted in Gohar and Sadeghi 2015, 755), LS is a psychological construct and is an important influence of achievement in education. Stevenson and Dunn (2001, as quoted in Gohar and Sadeghi 2015, 755) argue that students perform better when their study material is according to their learning style strength. Research has demonstrated that there is a link between academic performance and LS in university (Bailey, Onwuegbuzie and Daley 2000; Moeinikia and Zahed-Babelan 2010; Orhun 2012; Rasool and Rawaf 2008; Williams et al. 2013, as quoted in Gohar and Sadeghi 2015).

One study suggests that students make use of preferred methods to "receive, process and assimilate knowledge". (Andrassy and Torma 1982; as quoted in Kim et al. 2013, 32.) Increased learning efficiency can be attained by accommodating LS in teaching methods (Laight 2004; as quoted in Kim et al. 2013, 32). It has been pointed out that "[ $t]$ here is wide recognition of the impact of students' learning styles in education in general (e.g., Entwistle 1981; Entwistle 1991; Honey and Mumford 1992; Fleming 1995; Marriott and Marriott 2003; Goldfinch and Hughes 2007)" (as quoted in Gomez-Heras and McCabe 2014, 95) and that matching teaching style to preferred LS results in improved performance and learning (Fleming 1995; as quoted in Gomez-Heras and McCabe 2014, 95). 


\section{Criticisms of VARK and learning style}

Critics of LS mention that "Knowing one's learning style does not improve learning" (Fleming and Baume 2006, 6). They (Fleming and Baume 2006) do add, though, that knowing one's LS can be advantageous if the learner takes the next step. According to Murphy et al. (2004) matching lecturing methods to a LS does not necessarily improve learning. They (Murphy et al. 2004) proceed to emphasise that the best way to learn might not be within the preferred mode.

In a study by McKee (1995) it was found that the relationship between LS and academic achievement is imperceptible. Garton et al. (1999) established that a learners' achievement has a low positive relationship with their preferred LS. Sabeh et al. (2011) mention that there was no match between teaching style of teachers and learning of students. Coffield et al. (2004b) mentions that some of the best known LS instruments are weak with poor validity and low reliability.

Sometimes there is a mismatch between teaching and LS (Felder and Silverman 1988) which leads to "unfortunate consequences" (Khurshid 2015): for instance, students become bored, pay less attention in class, their test performance is poor (Felder and Silverman 1988). According to Cekiso (2011) there is controversy with regard to teaching styles and LS (Poldrack 2009 and Stephenson 2006 as quoted in Cekiso 2011). Current debates about LS and teaching styles have led to this disagreement (Poldrack 2009; Stephenson 2006). According to Cekiso (2011), many people have criticised LS theories. Greenfield (2007 as quoted in Henry 2007) argues that from a neuroscientific viewpoint, LS is absurd.

\section{Previous research on VARK}

Previous studies on VARK LS include Kumari (2013) who studied LS of high school learners in India in relation to their locus of control, gender and category. Kumari (2013) found significant differences and no significant differences between genders for Aural and Read/write LS and Visual and Kinaesthetic LS respectively. Allen, Swidler and Keiser (2013) subjected marketing communication students to the VARK questionnaire. A study of the reading achievement and LS of Saudi Arabian preparatory school learners was undertaken by Saadi (2012). Stevens, Kitterlin and Tanner (2012) assessed the LS of hospitality majors. In studies by Klement, Dostál and Marešová (2014) and Klement (2014), they requested education students to complete the VARK questionnaire. Ocepek, Bosnić, Ŝerbec, and Rugelj (2013) utilised the VAK questionnaire; their sample consisted of computer science, mathematics, primary teacher education, science, and art pedagogy students. A study by Nuzhat, Salem, Al 
Hamdan and Ashour (2013) examined gender differences in LS of fourth and fifth year medical students, while Prithishkumar and Michael (2014) studied first year undergraduate medical students. Nursing students' LS (Alkhasawneh 2013; Alkhasawneh, Mrayyan, Docherty, Alashram and Yousef 2008; James, D'Amore and Thomas 2011; and Marek 2013) were also investigated. In research by Vasileva-Stojanovska, Malinovski, Vasileva, Jovevski and Trajkovik (2015) they assessed K12 learners by means of the VARK questionnaire. Bhattacharyya and Shariff (2014) studied foundation level students in the disciplines of electrical and electronic engineering, civil engineering, chemical engineering, information technology, mechanical engineering, petroleum engineering, business information systems, and petroleum geosciences. In a study by Kim et al. (2013), they examined surgical residents' LS while general surgery residency applicants were participants in a study by Kim and Gilbert (2015). All residents of a general surgery residency programme were examined by Kim, Gilbert and Ristig (2015) and caregivers at an asthma/allergy clinic were studied by Dinakar, Adams, Brimer and Silva (2005). The Arabic version of the VARK questionnaire was administered to undergraduate dental male students in first to fifth years to determine their preferred LS (Asiry 2016. The VAK questionnaire was used to determine the LS profile and whether gender exerts any influence on the LS of the BEd I students, specialising in Economics and Management Sciences (Cekiso 2011). Gomez-Heras and McCabe's (2014) study involved geography students whereas sports therapy students were respondents in Wright, Duncan and SavinBaden's (2015) study.

\section{METHODOLOGY}

This study was conducted at Tshwane University of Technology (Pretoria, South Africa) in 2015. The structured, quantitative, VARK questionnaire was administered to third (final) year National Diploma: Logistics undergraduate students. The learners could choose more than one option for identifying their preferences for multiple LS. The study was approved by the institution's Central Ethics Committee. The questionnaires were distributed during class. It would take the learners about 20 minutes to complete the questionnaire. The options selected per student were read into the VARK questionnaire website page and the results were analysed and printed out.

Eighty (80) questionnaires were distributed to one group of Logistics III learners at Tshwane University of Technology. Logistics III is a major third year National Diploma: Logistics subject. During the year in question (2015) a cohort of 203 students were split into two groups of Logistics III students. Of the 80 questionnaires distributed, two were not received back, resulting in a response rate of 98 per cent ( 78 out of 80 ). Of the 78 questionnaires returned, 
two could not be used as not all the questions had been answered (a total of 76 useful questionnaires). From the VARK website (www.vark-learn.com), at least 12 of the 16 questions must be completed in order to provide an analysis response. Of the 78 respondents, 28 were male, 36 were female, while 14 provided no gender. The age distribution consisted of 56 in the 20-24 year age group, whereas 6 respondents were aged older than 25, and 16 respondents did not provide their age. Furthermore, the majority of these learners spoke a mother tongue other than English. These included Zulu, Afrikaans, Xhosa, Ndebele, Venda, Northern Sotho, Tsonga, Sotho, Tswana, and/or Swazi, with English sometimes being their second, third or fourth language. There are a number of international students as well, whose first language may be French.

Table 1 reports the gender distribution of the respondents. Thirty-six (36) (46.2\%) of the respondents were female and $28(35.9 \%)$ were male. Fourteen $14(17.9 \%)$ of the respondents did not select any gender.

Table 1: Research sample structure - Gender

\begin{tabular}{|l|c|c|}
\hline \multicolumn{1}{|c|}{ Gender } & Number & Percentage \\
\hline Men & 28 & 35.9 \\
\hline Women & 36 & 46.2 \\
\hline No gender given & 14 & 17.9 \\
\hline Total ${ }^{*}$ & 78 & 100 \\
\hline \multicolumn{2}{|c|}{${ }^{*}$ Total $=78$, as two questionnaires were not received back. }
\end{tabular}

Table 2 depicts the age distribution of the students. Fifty-six (56) (71.8\%) of the respondents are aged between 20-24 years of age. Those of 25 and above years of age numbered $6(7.7 \%)$. $16(20.5 \%)$ of the respondents did not complete the age field.

Table 2: Research sample structure - age

\begin{tabular}{|l|c|c|}
\hline \multicolumn{1}{|c|}{ Age } & Number & Percentage \\
\hline $20-24$ years & 56 & 71.8 \\
\hline$>25$ years & 6 & 7.7 \\
\hline No age given & 16 & 20.5 \\
\hline Total ${ }^{*}$ & 78 & 100 \\
\hline${ }^{*}$ Total $=78$, as two questionnaires were not received back.
\end{tabular}

Learning approaches for the VARK LS include:

1) Visual learners prefer graphs, maps, brochures, charts, diagrams, highlighters, pictures, word pictures, flow charts, various colours and fonts, written texts and designs, and different spatial arrangements.

2) Learners who are dominantly Aural prefer to discuss topics with their teachers and other 
students, explain new information to others, enter into debates/arguments, use a tape recorder, drama, music, use jokes and stories, and attend discussion groups and lectures.

3) Read/Write learners prefer lists, essays, definitions, Web pages, printed handouts, readings, reports, textbooks, manuals, written feedback, multiple choice, note taking, and bibliographies.

4) Kinaesthetic learners like trial and error, role play, field trips, doing things in order to understand them, guest lecturers, laboratories, working models, recipes, using their senses, solutions to problems, real-life examples, hands-on approaches, collections of samples, construction, and demonstrations (Hawk and Shah 2007; Fleming 2001).

\section{RESULTS}

Figure 1 illustrates the prevalence of the different LS preferences. The predominant learning preference amongst the Logistics III students was the K (kinaesthetic) (21 out of 76, 27.6\%), followed by the R (read/write) LS (15 out of 76, 19.7\%). The VARK learning preference was third with 10 out of $76(13.2 \%)$.

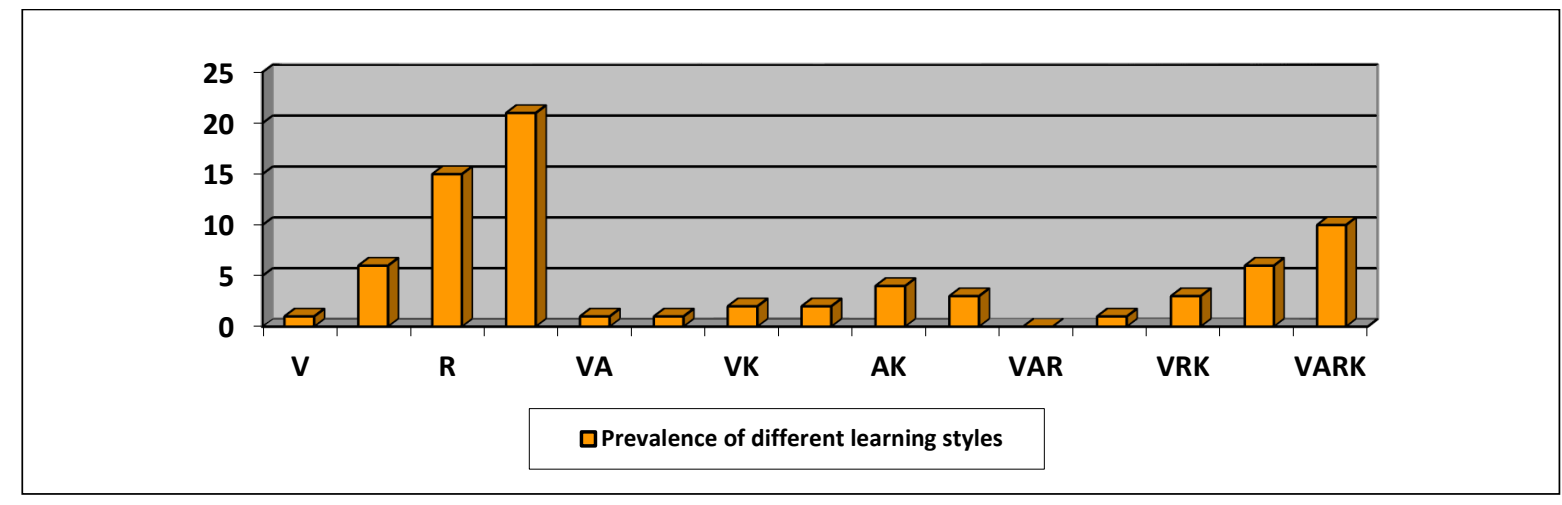

Figure 1: Prevalence of different learning styles

Table 3 provides the frequency and percentages of each gender categorised according to LS preference. Males were dominant in $\mathrm{K}$ (kinaesthetic) and tri-modal. Females were dominant in $\mathrm{K}$ (kinaesthetic) and R (read/write).

Table 3: Frequency and percentage of each gender categorised according to learning styles preference

\begin{tabular}{|c|c|c|c|c|c|c|c|c|c|c|}
\hline \multirow{2}{*}{\multicolumn{2}{|c|}{ Gender }} & \multicolumn{9}{|c|}{ Learning style preferences } \\
\hline & & \multirow{2}{*}{$\begin{array}{l}\mathbf{V} \\
0\end{array}$} & \multirow{2}{*}{$\frac{A}{1}$} & \multirow{2}{*}{$\begin{array}{c}\mathbf{R} \\
5\end{array}$} & \multirow{2}{*}{$\begin{array}{l}\mathbf{K} \\
6\end{array}$} & \multirow{2}{*}{$\begin{array}{c}\mathrm{Bi} \\
4\end{array}$} & \multirow{2}{*}{$\begin{array}{c}\text { Tri } \\
6\end{array}$} & \multirow{2}{*}{$\frac{\text { Quad }}{5}$} & \multirow{2}{*}{$\begin{array}{c}\mathbf{S} \\
12\end{array}$} & \multirow{2}{*}{$\begin{array}{c}\mathbf{M} \\
15\end{array}$} \\
\hline Mlo & $f$ & & & & & & & & & \\
\hline IVIales & $\%$ & 0 & 3.7 & 18.5 & 22.2 & 14.8 & 22.2 & 18.5 & 44.4 & 55.5 \\
\hline \multirow{2}{*}{ Females } & $f$ & 0 & 4 & 7 & 12 & 6 & 4 & 2 & 23 & 12 \\
\hline & $\%$ & 0 & 11.4 & 20 & 34.3 & 17.1 & 11.4 & 5.7 & 65.7 & 34.3 \\
\hline
\end{tabular}




\begin{tabular}{|c|c|c|c|c|c|c|c|c|c|c|}
\hline \multirow{2}{*}{\multicolumn{2}{|c|}{ Gender }} & \multicolumn{9}{|c|}{ Learning style preferences } \\
\hline & & \multirow{2}{*}{$\begin{array}{l}\mathbf{V} \\
1 \\
\end{array}$} & \multirow{2}{*}{$\begin{array}{c}\mathbf{A} \\
1 \\
\end{array}$} & \multirow{2}{*}{$\begin{array}{l}\mathbf{R} \\
3 \\
\end{array}$} & \multirow{2}{*}{$\begin{array}{l}K \\
3 \\
\end{array}$} & \multirow{2}{*}{$\begin{array}{c}\mathbf{B i} \\
3 \\
\end{array}$} & \multirow{2}{*}{$\begin{array}{c}\text { Tri } \\
0 \\
\end{array}$} & \multirow{2}{*}{$\begin{array}{c}\text { Quad } \\
3 \\
\end{array}$} & \multirow{2}{*}{$\begin{array}{l}\mathbf{S} \\
8 \\
\end{array}$} & \multirow{2}{*}{$\begin{array}{c}\mathbf{M} \\
6\end{array}$} \\
\hline No gonder & $f$ & & & & & & & & & \\
\hline INo genduer & $\%$ & 7.1 & 7.1 & 21.4 & 21.4 & 21.4 & 0 & 21.4 & 57.1 & 42.9 \\
\hline \multirow{2}{*}{ Total } & $f$ & 1 & 6 & 15 & 21 & 13 & 10 & 10 & 43 & 33 \\
\hline & $\%$ & 1.3 & 7.9 & 19.7 & 27.6 & 17.1 & 13.2 & 13.2 & 56.6 & 43.4 \\
\hline
\end{tabular}

Abbreviations note: $\mathrm{S}=$ single style, $\mathrm{Bi}=$ bi style, Tri = tri style, Quad = quad style, $\mathrm{M}=$ multimodal style,

$\mathrm{R}=\mathrm{read} / \mathrm{write}, \mathrm{A}=$ aural, $\mathrm{V}=$ visual, $\mathrm{K}=$ kinaesthetic

Male total is 27 , since one respondent did not complete the necessary number of questions. Females total is 35 , as one respondent did not complete the necessary number of questions.

Table 4 records the frequency and percentages of each age group categorised according to LS preference. In the 20-24 age group the dominant mode was K (kinaesthetic) followed by bimodal and $\mathrm{R}$ (read/write). For the above 25 age group the dominant styles were A (aural), $\mathrm{R}$ (read/write) and quad style.

Table 4: Frequency and percentage of each age group categorised according to learning styles preference

\begin{tabular}{|c|c|c|c|c|c|c|c|c|c|c|}
\hline \multirow{2}{*}{\multicolumn{2}{|c|}{ Age group }} & \multicolumn{9}{|c|}{ Learning style preferences } \\
\hline & & \multirow{2}{*}{$\begin{array}{l}\mathbf{V} \\
0\end{array}$} & \multirow{2}{*}{$\begin{array}{l}\text { A } \\
3\end{array}$} & \multirow{2}{*}{$\begin{array}{l}\mathbf{R} \\
10\end{array}$} & \multirow{2}{*}{$\begin{array}{l}\mathbf{K} \\
18\end{array}$} & \multirow{2}{*}{$\begin{array}{l}\mathbf{B i} \\
10\end{array}$} & \multirow{2}{*}{$\begin{array}{c}\text { Tri } \\
8\end{array}$} & \multirow{2}{*}{$\begin{array}{c}\text { Quad } \\
5\end{array}$} & \multirow{2}{*}{$\begin{array}{c}\mathbf{S} \\
31\end{array}$} & \multirow{2}{*}{$\begin{array}{l}\mathbf{M} \\
23 \\
\end{array}$} \\
\hline $20-21$ & f & & & & & & & & & \\
\hline $20-24$ & $\%$ & 0 & 5.6 & 18.5 & 33.3 & 18.5 & 14.8 & 9.3 & 57.4 & 42.6 \\
\hline \multirow{2}{*}{$>25$} & f & 0 & 2 & 2 & 0 & 0 & 1 & 2 & 4 & 3 \\
\hline & $\%$ & 0 & 28.6 & 28.6 & 0 & 0 & 14.3 & 28.6 & 57.1 & 42.9 \\
\hline \multirow{2}{*}{ No age } & f & 1 & 1 & 3 & 3 & 3 & 1 & 3 & 8 & 7 \\
\hline & $\%$ & 6.7 & 6.7 & 20 & 20 & 20 & 6.7 & 20 & 53.3 & 46.7 \\
\hline \multirow{2}{*}{ Total } & f & 1 & 6 & 15 & 21 & 13 & 10 & 10 & 43 & 33 \\
\hline & $\%$ & 1.3 & 7.9 & 19.7 & 27.6 & 17.1 & 13.2 & 13.2 & 56.6 & 43.4 \\
\hline
\end{tabular}

Abbreviations note: $\mathrm{S}=$ single style, $\mathrm{Bi}=$ bi style, Tri $=$ tri style, Quad = quad style, $\mathrm{M}=$ multimodal style, $\mathrm{R}=$ $\mathrm{read} / \mathrm{write}, \mathrm{A}=$ aural, $\mathrm{V}=$ visual, $\mathrm{K}=$ kinaesthetic.

Age group of 20-24 total is 54 , since two respondents did not complete the necessary number of questions. Age group of $>25$ years total is 6 . No age provided total is 16 .

In the study 56.6 per cent and 43.4 per cent of the learners preferred unimodal $(\mathrm{V}, \mathrm{A}, \mathrm{R}$ or $\mathrm{K})$ learning and multimodal (AR, AK, RK, VR, VA, VK, VAK, VAR, ARK, VRK, or VARK) LS respectively (Figure 2).

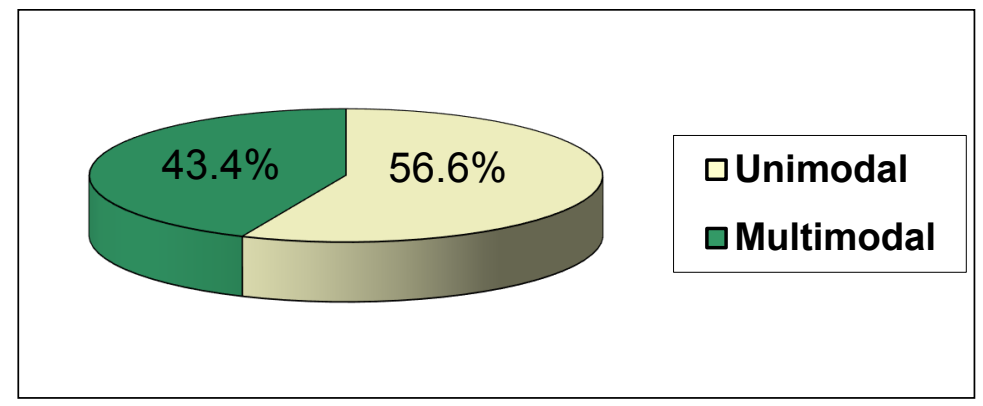

Figure 2: Distribution of unimodal and multimodal learning styles 
Of those learners who preferred a multimodal LS, 39.4 per cent were bimodal (VA, VK, VR, AK, AR, or RK), 30.3 per cent were trimodal (ARK, VAK, VAR, or VRK) and 30.3 per cent were quadmodal (VARK) (figure 3). For multimodal learnersm the preferred style is bimodal.

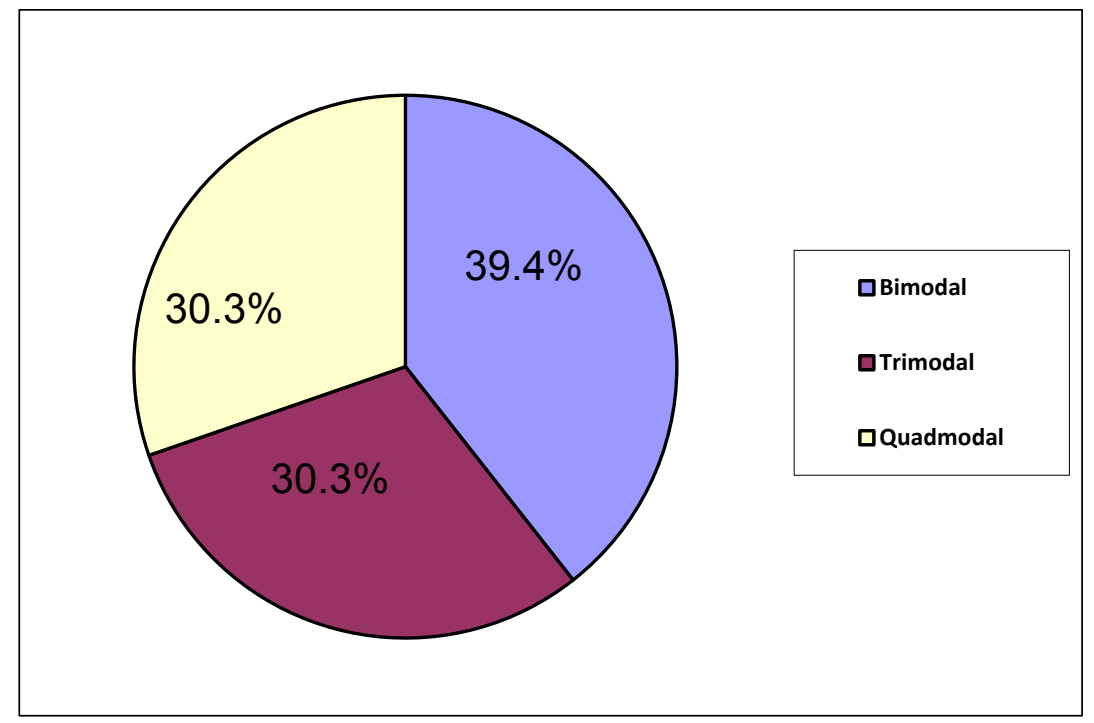

Figure 3: Distribution of multimodal learning styles

Of the unimodal (V, A, R or K) students, 2.33 per cent of the learners preferred $\mathrm{V}, 13.95$ per cent preferred A, 34.88 per cent preferred $\mathrm{R}$ while 48.84 per cent of the learners preferred $\mathrm{K}$ (Figure 4). Therefore the kinaesthetic learning preference is the dominant among unimodal students, followed by read/write.

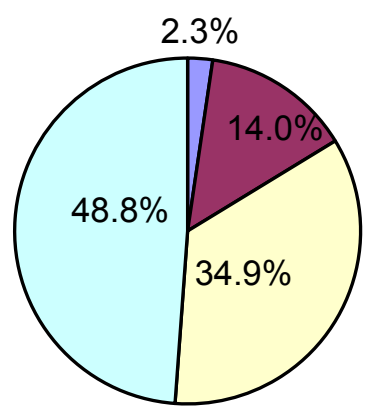

Figure 4: Distribution of unimodal learning styles 
On further analysis the predominant learning preference of the bimodal learners was AK (30.8\%), followed by RK (23.1\%), VK and AR (15.4\% each) and VA and VR (7.7\% each) preferences (Figure 5). Amongst those learners who preferred tri-modal LS, 10 per cent were VAK, 60 per cent were ARK, and 30 per cent were VRK (Figure 6). No learners were VAR.

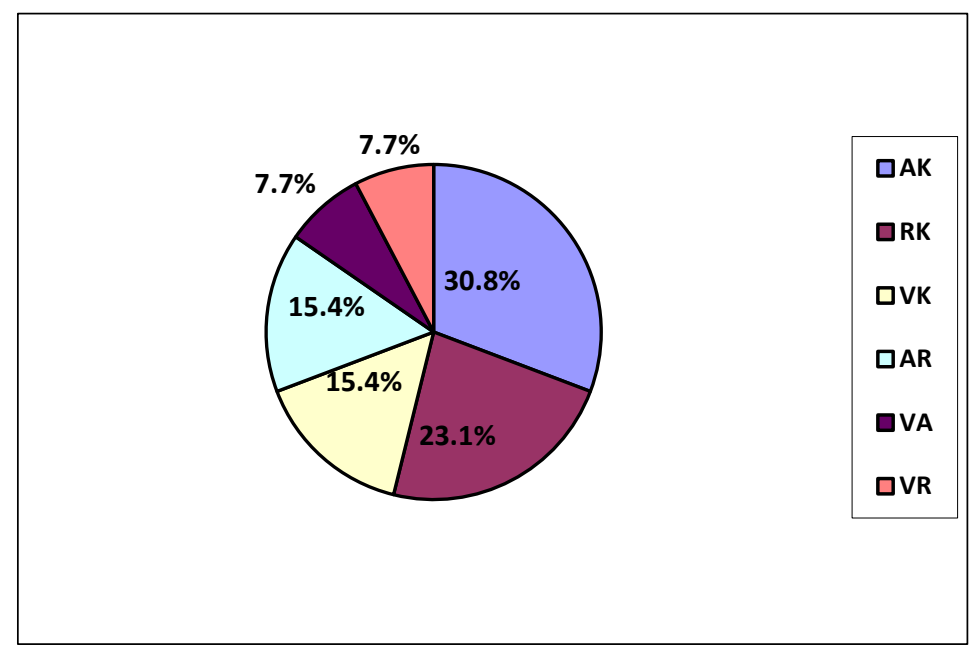

Figure 5: Distribution of bi-modal learning styles

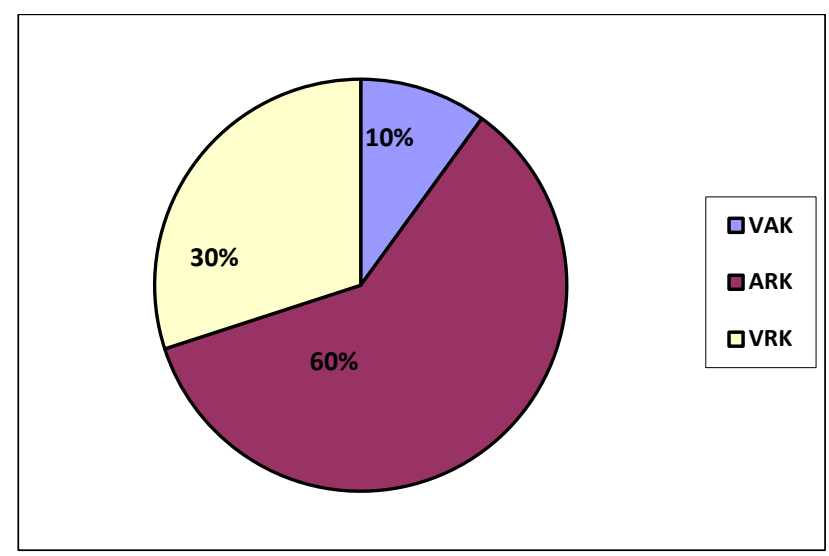

Figure 6: Distribution of tri-modal learning styles

In Figure 7 the student LS preferences with regards to individual learning modalities is shown. This indicates the number of learners who had each modality as a component of their overall LS preference. The sum of the students for the four modalities exceeds 78 (number of questionnaires received back) because students with multimodal preferences are counted more than once. Overall, 50 learners had a K learning preference. Only 19 had a V learning preference. 


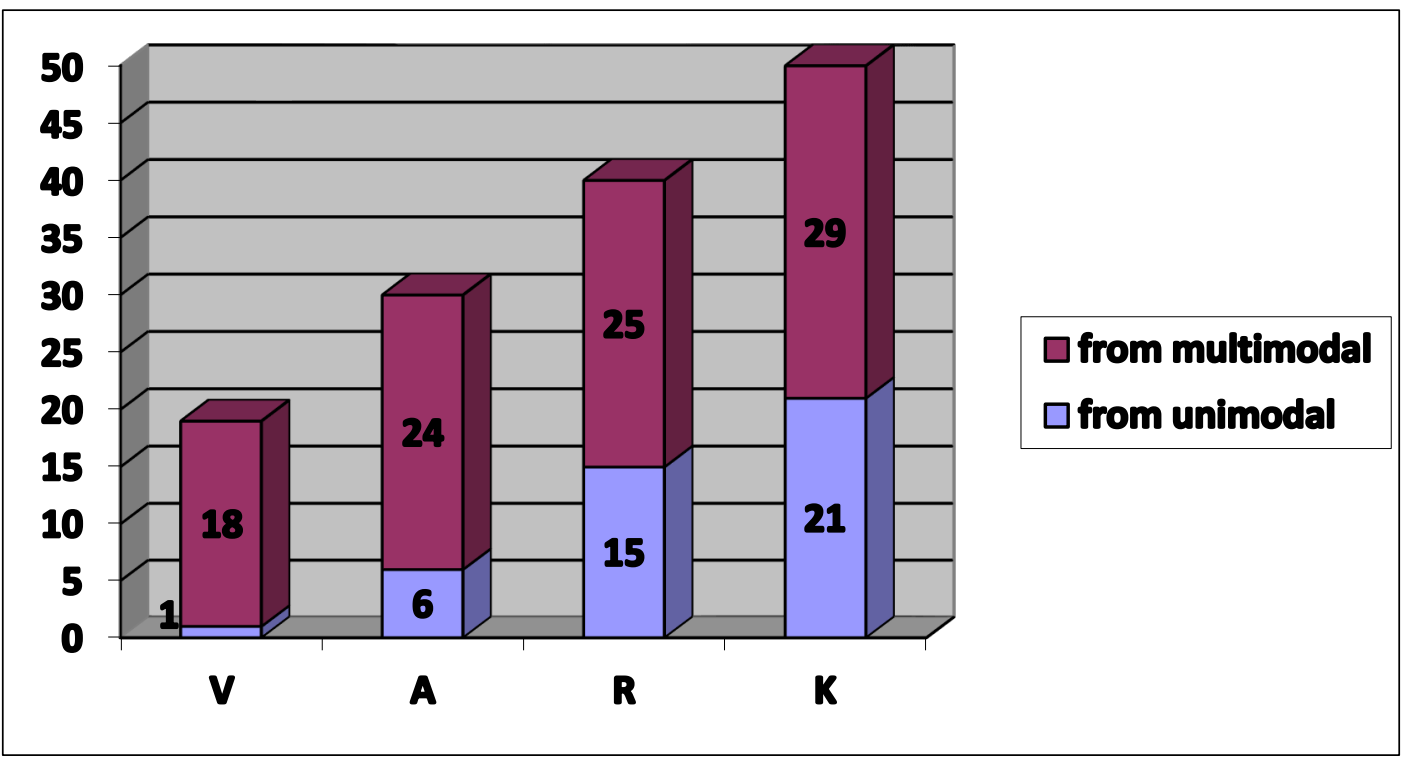

Figure 7: Prevalence of individual learning modalities among student learning style preference

Of the 78 questionnaires received back, 76 were useful in that the VARK website could analyse the responses. The remaining two questionnaires had insufficient boxes ticked (missing data) and could not be analysed. In Figure 8 below, the prevalence of LS modalities percentages is portrayed. Note that the total is more than 100 per cent since students with multimodal preferences are counted more than once. Sixty-six percent of the students (50 of 76) had some degree of kinaesthetic (K) learning preference, while 25 per cent (19 of 76) were visual (V) learners.

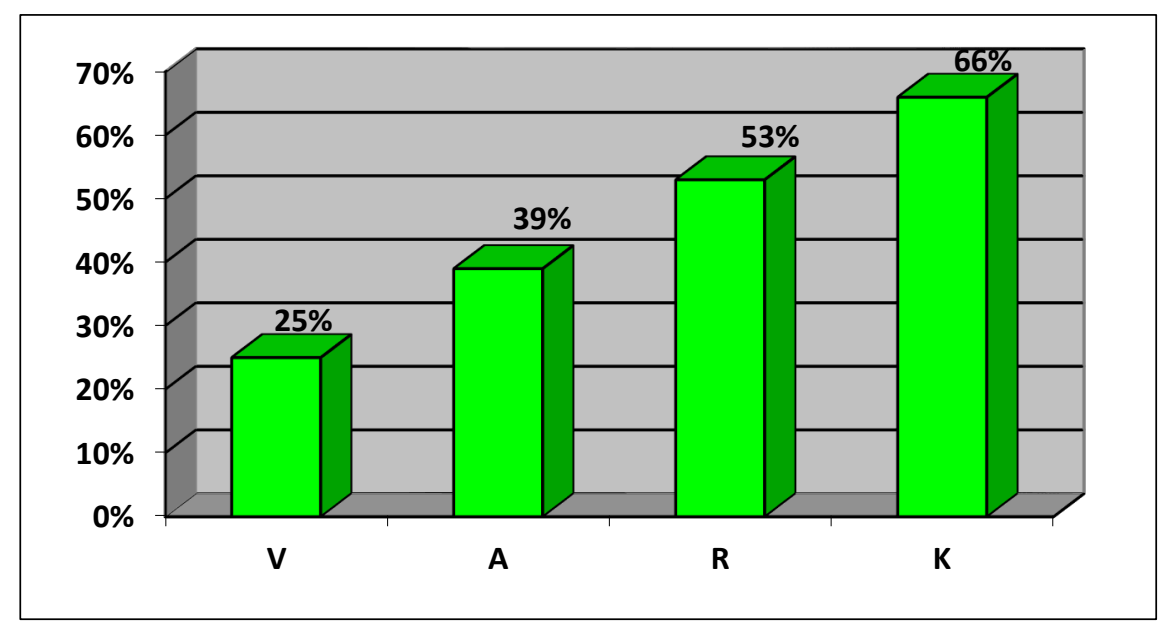

Figure 8: Prevalence of individual learning modalities percentages among student learning style preference

\section{LIMITATIONS}

This study has a limitation. Firstly it was conducted at one institution involving one group of 
final year Diploma: Logistics students. The participating number of students does not necessarily represent all Logistics students in South Africa; hence the results should not be generalised.

\section{CONCLUDING THOUGHTS AND RECOMMENDATIONS}

Future research in this field could comprise employing the questionnaire with a cohort of Logistics Diploma (first, second and third year) students. Also it might include Logistics Foundation (extended programme: pre-first year) and BTech (Baccalaureus Technologiae) students and possibly postgraduate students. Further research involving many more Logistics students from various universities and at different year of study is needed. In addition, other management sciences subjects/qualifications could also be included. Furthermore, a comparative study could be carried out, requesting the students to complete the questionnaire in January, then altering the researcher's class teaching style to suit their LS preference and putting them through the questionnaire in October to see if there will be any significant differences in their LS.

\section{ACKNOWLEDGEMENTS}

Author contribution: the author contributed to the study's conception, design, acquisition; the analysis and interpretation of the data as well as undertaking the drafting and critical revision of this article. A thank you to his students for completing the questionnaire.

\section{DISCLOSURE}

The VARK questionnaire was used with permission. The VARK copyright is held by Neil D. Fleming, Christchurch, New Zealand. The author has no conflicts of interest related to this work.

\section{REFERENCES}

Ackland-Tilbrook, V. and J. Warland. 2015. Open the VALT ${ }^{\mathrm{TM}}$ : Creation and application of a visually authentic learning tool. Nurse Education in Practice 15: 249-252. www.elsevier.com (Accessed 26 November 2015).

Al Shaikh, A. 2015. Learning styles and satisfaction with educational activities among paediatric physicians at King Abdulaziz Medical City Jeddah. Journal of Taibah University Medical Sciences 10(1): 102-108. www.sciencedirect.com (Accessed 26 November 2015).

Alkhasawneh, E. 2013. Using VARK to assess changes in learning preferences of nursing students at a public university in Jordan: Implications for teaching. Nurse Education Today 33: 1546-1549. www.elsevier.com (Accessed 11 November 2014).

Alkhasawneh, I. M., M. T. Mrayyan, C. Docherty, S. Alashram and H. Y. Yousef. 2008. Problem-based learning (PBL): Assessing students' learning preferences using VARK. Nurse Education Today 28(5): 572-579. 
Allen, S., M. Swidler and J. Keiser. 2013. Aligning pedagogy of American business language with marketing students' preferred learning styles. Procedia - Social and Behavioral Studies 70: 12541264. www.sciencedirect.com (Accessed 26 November 2015).

Andrassy, R. J. and M. J. Torma. 1982. Learning styles and the prospective surgeon. Am Surg 48: 293296, quoted in Kim, R. H., T. Gilbert, K. Ristig and Q. D. Chu. 2013. Surgical resident learning styles: Faculty and resident accuracy at identification of preferences and impact on ABSITE scores. Journal of Surgical Research 184: 31-36. www.sciencedirect.com

Asiry, M. A. 2016. Learning styles of dental students. The Saudi Journal for Dental Research 7(1): 1317. www.sciencedirect.com (Accessed 15 April 2016).

Bhattacharyya, E. and A. B. M. S. Shariff. 2014. Learning style and its impact in higher education and human capital needs. Procedia - Social and Behavioral Sciences 123: 485-494. www.sciencedirect.com (Accessed 26 November 2015).

Bailey, P., A. J. Onwuegbuzie and C. E. Daley. 2000. Using learning style to predict foreign language achievement at the college level. System 28: 115-133. http://dx.doi.org/10.1016/S0346-251X (99)00064-0, quoted in Gohar, M. J. and N. Sadeghi. 2015. The impact of learning style preferences on foreign language achievement: A case study of Iranian EFL students. ProcediaSocial and Behavioral Sciences 171: 754-764. www.sciencedirect.com

Cekiso, M. P. 2011. Profiling learning style preferences of first-year university students: Implications for course design and instruction. South African Journal of Higher Education 25(7): 1298-1309.

Chang, C. Y. 2005. Relating listening strategies to EFL learners' learning styles. LATEFL 2005, Cardiff UK, quoted in Cekiso, M. P. 2011. Profiling learning style preferences of first-year university students: Implications for course design and instruction. South African Journal of Higher Education 25(7): 1298-1309.

Chang, C. Y. 2006. TIRF Computer-Based Technology: The relationship between individual learning styles and learning strategies in electronic materials for practicing EFL listening. The 40th TESOL convention and Exhibit, Tampa, 15-19 March 2006, quoted in Cekiso, M. P. 2011. Profiling learning style preferences of first-year university students: Implications for course design and instruction. South African Journal of Higher Education 25(7): 1298-1309.

Chiou, W. B. 2008. College students' role models, learning style preferences, and academic achievement in collaborative teaching: Absolute versus relativistic thinking. Adolescence 43(169): 129-142.

Coffield, F., D. Moseley, E. Hall and K. Ecclestone. 2004a. Learning styles and pedagogy in post-16 learning: A systematic and critical review. London: Learning and Skills Research Centre.

Coffield, F., D. Moseley, E. Hall and K. Ecclestone. 2004b. Should we be using learning styles? What research has to say to practice. London: Learning and Skills Research Centre.

Dinakar, C., C. Adams, A. Brimer and M. Silva. 2005. Learning preferences of caregivers of asthmatic children. Journal of Asthma 42: 683-687.

Drago, W. A. and R. J. Wagner. 2004. Vark preferred learning styles and online education. Management Research News 27(7): 1-13. www.emeraldinsight.com (Accessed 15 April 2016).

Dunn, R. and S. A. Griggs. 2000. Practical approaches to using learning styles in higher education. Westpot, CT: Bergin and Garvey, quoted in Cekiso, M. P. 2011. Profiling learning style preferences of first-year university students: Implications for course design and instruction. South African Journal of Higher Education 25(7): 1298-1309.

Entwistle, N. 1981. Styles of learning and teaching. John Wiley \& Sons, New York, quoted in GomezHeras, M. and S. McCabe. 2014. Student learning styles. Chapter 4.1. In Developments in Earth Surface Processes, ed. M. Thornbush, C. Allen, F. Fitzpatrick, 18. Geomorphological Fieldwork.

Entwistle, N. 1991. 'How students learn and why they fail'. In Talent, teaching and achievement, ed. J. Radford and Jessica Kingsley, 77-96, London, quoted in Gomez-Heras, M. and S. McCabe. 2014. Student learning styles. Chapter 4.1. In Developments in earth surface processes, ed. M. Thornbush, C. Allen and F. Fitzpatrick, 18. Geomorphological Fieldwork.

Felder, R. M. and L. K. Silverman. 1988. Learning and teaching styles in engineering education. Engr. 
Education 78(7): 674-681. http://www4.ncsu.edu (Accessed 17 October 2016).

Felder, R. and R. Brent. 2005. Understanding students' differences. Journal of Engineering Education 94(1): 57-72, quoted in Alkhasawneh, E. 2013. Using VARK to assess changes in learning preferences of nursing students at a public university in Jordan: Implications for teaching. Nurse Education Today 33: 1546-1549. www.elsevier.com

Fleming, N. D. 1995. I'm different; not dumb: Modes of presentation (VARK) in the tertiary classroom. In Research and Development in Higher Education, Proceedings of the 1995 Annual Conference of the Higher Education and Research Development Society of Australasia (HERDSA), ed. A. Zelmer, 18: 308-313.

Fleming, N. D. 2001. Teaching and learning styles: VARK strategies. Christchurch, New Zealand: N.D. Fleming.

Fleming, N. and D. Baume. 2006. Learning styles again: VARKing up the right tree! Educational Developments, SEDA Ltd. 7.4(November): 4-7.

Fleming, N. D. and C. Mills. 1992. Not another inventory, rather a catalyst for reflection. To Improve the Academy 11: 137-155.

Garton, B., J. Spain, W. Lamberson and D. Spiers. 1999. Learning styles, teaching performance, and student achievement: A relational study. Journal of Agricultural Education 40(3): 11-20. doi:10.5032/jae.1999.03011.

Gohar, M. J. and N. Sadeghi. 2015. The impact of learning style preferences on foreign language achievement: A case study of Iranian EFL students. Procedia - Social and Behavioral Sciences 171: 754-764. www.sciencedirect.com (Accessed 26 November 2015).

Goldfinch, J. and M. Hughes. 2007. Skills, learning and success of first-year undergraduates. Active Learning in Higher Education 8(3): 259-273, quoted in Gomez-Heras, M. and S. McCabe. 2014. Student learning styles. Chapter 4.1. In Developments in earth surface processes, ed. M. Thornbush, C. Allen and F. Fitzpatrick, 18. Geomorphological Fieldwork.

Gomez-Heras, M. and S. McCabe. 2014. Student learning styles. Chapter 4.1. In Developments in Earth Surface Processes, ed. M. Thornbush, C. Allen, F. Fitzpatrick, 18. Geomorphological Fieldwork.

Goldsworthy, S., 2012. High fidelity simulation in critical care: A Canadian perspective. Collegian 19: 139-143, quoted in Ackland-Tilbrook, V. and J. Warland. 2015. Open the VALT TM: Creation and application of a visually authentic learning tool. Nurse Education in Practice 15: 249-252. www.elsevier.com

Greenfield, S. 2007. Baroness, the Director of the Royal Institute, quoted in Henry, J. 2007. Professor pans 'learning style' teaching method. http://www.telegraph.co.uk/news/uknews/1558822/ Professor-pans-learning-style-teaching-method.html

Hallin, K. 2014. Nursing students at a university: A study about learning style preferences. Nurse Education Today 34: 1443-1449. www.elsevier.com (Accessed 26 November 2015).

Hardigan, P. C. and S. R. Cohen. 2003. A comparison of learning styles among seven health professions: Implications for optometric education. The Internet Journal of Allied Health Sciences and Practice 1(1): 1-7, quoted in Marek, G. I. 2013. Impact of learning style assessment on selfreported skills of students in an associate degree nursing program. Teaching and Learning in Nursing 8: 43-49.

Hawk, T. F. and A. J. Shah. 2007. Using learning style instruments to enhance student learning. Decision Sciences Journal of Innovative Education 5(1): 1-19.

Henry, J. 2007. Professor pans 'learning style' teaching method. http://www.telegraph.co.uk/ news/uknews/1558822/Professor-pans-learning-style-teaching-method.html (Accessed 29 May 2017).

Herod, L. 2004. Learning styles and strategies. https://www.gov.mb.ca/mal/all/publications/ learning_styles_and_strategies_aug_2004.pdf (Accessed 28 January 2016).

Herrington, J. and Herrington. 2006. Authentic e-learning in higher education: Design principles for authentic learning environments and tasks. In World Conference on E-learning in Corporate, 
Government, Healthcare, and Higher Education, Chesapeake, Va, quoted in Ackland-Tilbrook, V. and J. Warland. 2015. Open the VALT TM: Creation and application of a visually authentic learning tool. Nurse Education in Practice 15: 249-252. www.elsevier.com

Honey, P. and A. Mumford. 1992. Manual of learning styles. Honey Publications, Maidenhead, quoted in Gomez-Heras, M. and S. McCabe. 2014. Student learning styles. Chapter 4.1. In Developments in Earth Surface Processes, ed. M. Thornbush, C. Allen and F. Fitzpatrick, 18. Geomorphological Fieldwork.

James, S., A. D'Amore and T. Thomas. 2011. Learning preferences of first year nursing and midwifery students: Utilising VARK. Nurse Education Today 31(4): 417-423.

Jung, C. G. 1971. Psychological types. Princeton, NJ: Princeton University Press.

Keefe, J. W. 1979. Learning style: An overview. Student learning styles: Diagnosing and prescribing programs, 1-17, quoted in Truong, H. M. 2016. Integrating learning styles and adaptive eLearning system: Current developments, problems and opportunities. Computers in Human Behavior 55(part B): 1185-1193. www.sciencedirect.com

Khurshid, Z. S. 2015. The charismatic blend of learning and teaching styles in the cross-cultural scenario of Jazan University. Procedia - Social and Behavioral Sciences 192: 275-283. www.sciencedirect.com (Accessed 26 November 2015).

Kim, R. H. and T. Gilbert. 2015. Learning style preferences of surgical residency applicants. Journal of Surgical Research 198: 61-65. www.sciencedirect.com (Accessed 26 November 2015).

Kim, R. H., T. Gilbert and K. Ristig. 2015. The effect of surgical resident learning style preferences on American Board of Surgery in-training examination scores. Journal of Surgical Education 72(4): 726-731. www.sciencedirect.com (Accessed 26 November 2015).

Kim, R. H., T. Gilbert, K. Ristig and Q. D. Chu. 2013. Surgical resident learning styles: Faculty and resident accuracy at identification of preferences and impact on ABSITE scores. Journal of Surgical Research 184: 31-36. www.sciencedirect.com (Accessed 26 November 2015).

Klement, M. 2014. How do my students study? An analysis of students' of educational disciplines favorite learning styles according to VARK classification. Procedia - Social and Behavioral Sciences 132: 384-390. www.sciencedirect.com (Accessed 26 November 2015).

Klement, M., J. Dostál and H. Marešová. 2014. Elements of electronic teaching materials with respect to student's cognitive learning styles. Procedia - Social and Behavioral Sciences 112: 437-446. www.sciencedirect.com (Accessed 26 November 2015).

Kolb, A. and D. Kolb. 2010. Experiential learning theory: A dynamic, holistic approach to management learning, education and development. In Handbook of management learning, education and development, ed. S. Armstrong and C. Fukami. London: Sage Publications.

Kumari, N. 2013. A study of learning styles of high school students in relation to their gender, category and locus of control. Master of Philosophy in Education. Himacha L Pradesh University. Summerhill, Shimla. Published.

Laight, D. W. 2004. Attitudes to concept maps as a teaching/learning activity in undergraduate health professional education: Influence of preferred learning style. Med Teach 26: 229-233, quoted in Kim, R. H., T. Gilbert, K. Ristig and Q. D. Chu. 2013. Surgical resident learning styles: Faculty and resident accuracy at identification of preferences and impact on ABSITE scores. Journal of Surgical Research 184: 31-36. www.sciencedirect.com

Lesmes-Anel, J., G. Robinson and S. Moody. 2001. Learning preferences and learning styles: A study of Wessex general practice registra[r]s. British Journal of General Practice 51: 559-564, quoted in Alkhasawneh, E. 2013. Using VARK to assess changes in learning preferences of nursing students at a public university in Jordan: Implications for teaching. Nurse Education Today 33: 1546-1549. www.elsevier.com

Lovelace, M. K. 2005. Meta-analysis of experimental research based on the Dunn and Dunn model. Journal of Educational Research 98(3): 176-183. 
Lujan, H. and DiCarlo. 2006. First year medical students prefer multiple learning styles. Advances in Physiology Education 30: 13-16, quoted in Alkhasawneh, E. 2013. Using VARK to assess changes in learning preferences of nursing students at a public university in Jordan: Implications for teaching. Nurse Education Today 33: 1546-1549. www.elsevier.com

Mandela, N. n.d. Education is the most powerful weapon which you can use to change the world. http://www.brainyquote.com/quotes/quotes/n/nelsonmand157855.html (Accessed 19 October 2016).

Marcy, V. 2001. Adult learning styles: How the VARK Learning Styles Inventory can be used to improve student learning. Perspectives on Physician Assistant Education 12(2): 117-120.

Marek, G. I. 2013. Impact of learning style assessment on self-reported skills of students in an associate degree nursing program. Teaching and Learning in Nursing 8: 43-49.

Marriott, N. and P. Marriott. 2003. Student learning style preferences and undergraduate academic performance at two UK universities. Int. J. Manage. Educ. 3(1): 4-13, quoted in Gomez-Heras, M. and S. McCabe. 2014. Student learning styles. Chapter 4.1. In Developments in earth surface processes, ed. M. Thornbush, C. Allen and F. Fitzpatrick, 18. Geomorphological Fieldwork.

Mckee, J. 1995. Learning style preferences, academic achievement and academic majors in college students: An exploratory study. Doctoral dissertation. Available from ProQuest Dissertation and theses databases. (UMI No: 9527516).

Meehan-Andrews, T. A. 2009. Teaching mode efficiency and learning preferences of first year nursing students. Nurse Education Today 29: 24-32. http://dx.doi.org/10.1016/j.nedt.2008.06.07, quoted in Marek, G. I. 2013. Impact of learning style assessment on self-reported skills of students in an associate degree nursing program. Teaching and Learning in Nursing 8: 43-49.

Miller, P. 2001. 'Learning styles: The multimedia of the mind. Research Report'. (ED451140), quoted in Cekiso, M. P. 2011. Profiling learning style preferences of first-year university students: Implications for course design and instruction. South African Journal of Higher Education 25(7): 1298-1309.

Moenikia, M. and A. Zahed-Babelan. 2010. The role of learning styles in second language learning among distance education students. Procedia - Social and Behavioral Sciences 2: 1169-1173, quoted in Gohar, M. J. and N. Sadeghi. 2015. The impact of learning style preferences on foreign language achievement: A case study of Iranian EFL students. Procedia - Social and Behavioral Sciences 171: 754-764. www.sciencedirect.com

Murphy, R. J., S. A. Gray, S. R. Straja and M. C. Bogert. 2004. Student learning preferences and teaching implications. Journal of Dental Education 68(8): 859-866.

Noble, K. A., S. M. Miller and J. Heckman. 2008. The cognitive style of nursing students: Educational implications for teaching and learning. The Journal of Nursing Education 47(6): 245-253, quoted in Marek, G. I. 2013. Impact of learning style assessment on self-reported skills of students in an associate degree nursing program. Teaching and Learning in Nursing 8: 43-49.

Nuzhat, A., R. O. Salem, N. A. Hamdan and N. Ashour. 2013. Gender differences in learning styles and academic performance of medical students in Saudi Arabia. Medical Teacher 35: S78-S82.

Ocepek, U., Z. Bosnić, I. N. Ŝerbec and J. Rugelj. 2013. Exploring the relation between learning style models and preferred multimedia types. Computers and Education 69: 343-355. www.elsevier.com (Accessed 26 November 2015).

Orhun, N. 2012. The relationship between learning styles and achievement in calculus course for engineering students. Procedia - Social and Behavioral Sciences, 47: 638-642, quoted in Gohar, M. J. and N. Sadeghi. 2015. The impact of learning style preferences on foreign language achievement: A case study of Iranian EFL students. Procedia - Social and Behavioral Sciences 171: 754-764. www.sciencedirect.com

Othman, N. and M. H. Amiruddin. 2010. Different perspectives of learning styles from VARK Model. Procedia - Social and Behavioral Sciences 7(C): 652-660.

Poldrack, R. 2009. Are 'learning styles' important in teaching methods? http://www.huffingtonpost. 
com/russell-poldrack/are-learning-styles-impor-b-398326.html (Accessed 4 February 2010), quoted in Cekiso, M. P. 2011. Profiling learning style preferences of first-year university students: Implications for course design and instruction. South African Journal of Higher Education 25(7): 1298-1309.

Prithishkumar, I. J. and S. A. Michael. 2014. Understanding your student: Using the VARK model. Journal of Postgraduate Medicine 60(2): 183-186.

Rasool, H. and S. Rawaf. 2008. The influence of learning styles preference of undergraduate nursing students on educational outcomes in substance use education. Nurse Education in Practice 8: 306314, quoted in Gohar, M. J. and N. Sadeghi. 2015. The impact of learning style preferences on foreign language achievement: A case study of Iranian EFL students. Procedia - Social and Behavioral Sciences 171: 754-764. www.sciencedirect.com

Rinaldi, C. and R. Gurung. 2008. Should teaching and learning styles match? Teaching Forum: A Journal of the Scholarship of Teaching and Learning http://www.uwosh.edu/programs/ teachingforum/public_html/?module=displaystoryandstory_id=648 (Accessed 21 September 2016).

Saadi, I. A. 2012. An examination of the learning styles of Saudi preparatory school students who are high or low in reading achievement. Unpublished Doctor of Philosophy thesis. School of Education. Faculty of Arts, Education, and Human Development. Victoria University, Melbourne, Australia.

Sabeh, G., R. Bahous, N. N. Bacha and M. Nabhani. 2011. A match or a dismatch between student and teacher learning style preferences. International Journal of Linguistics 1(1): 162-172.

Shannon, S. V. 2008. Using metacognitive strategies and learning styles to create self-directed learners. Institute for Learning Styles Journal, 1: 14-26, quoted in Marek, G. I. 2013. Impact of learning style assessment on self-reported skills of students in an associate degree nursing program. Teaching and Learning in Nursing 8: 43-49.

Sims, R. R., J. G. Veres and L. G. Shake. 1989. An exploratory examination of the convergence between the learning style questionnaire and the revised learning style inventory. Educational \& Psychological Measurement 49: 227-233, quoted in Gohar, M. J. and N. Sadeghi. 2015. The impact of learning style preferences on foreign language achievement: A case study of Iranian EFL students. Procedia - Social and Behavioral Sciences 171: 754-764. www.sciencedirect.com

Stephenson, R. 2006. 'Open Source/open course learning' innovative online journal. http://www.inno vateonline.info/index.php?view=article Soid $=345$, quoted in Cekiso, M. P. 2011. Profiling learning style preferences of first-year university students: Implications for course design and instruction. South African Journal of Higher Education 25(7): 1298-1309.

Stevens, D. P., M. Kitterlin and J. R. Tanner. 2012. Assessing the impact of learning styles for hospitality students. Consortium Journal of Hospitality and Tourism 17: 1-23.

Stevenson, J. and R. Dunn. 2001. Knowledge management and learning styles: Prescriptions for future teachers. College Student Journal 35(4): 483-490, quoted in Gohar, M. J. and N. Sadeghi. 2015. The impact of learning style preferences on foreign language achievement: A case study of Iranian EFL students. Procedia - Social and Behavioral Sciences 171: 754-764. www.sciencedirect.com

Stewart, K. L. and L. A. Felicetti. 1992. Learning styles of marketing majors. Educational Research Quarterly 15: 15-23.

Stitt-Gohdes, W. L. 2003. Student teachers and their students; Do their instructional and learning preferences match? Business Education Forum 57(4): 22-27, quoted in Cekiso, M. P. 2011. Profiling learning style preferences of first-year university students: Implications for course design and instruction. South African Journal of Higher Education 25(7): 1298-1309.

Taekman, J. and K. Shelley. 2010. Virtual environments in Healthcare: Immersion, disruption, and flow. Int. Anesthesiol. Clin. 48: 101-121, quoted in Alkhasawneh, E. 2013. Using VARK to assess changes in learning preferences of nursing students at a public university in Jordan: Implications for teaching. Nurse Education Today 33: 1546-1549. www.elsevier.com

Truong, H. M. 2016. Integrating learning styles and adaptive e-Learning system: Current developments, 
problems and opportunities. Computers in Human Behavior 55(part B): 1185-1193. www.sciencedirect.com (Accessed 15 April 2016).

Vasileva-Stojanovska, T., T. Malinovski, M. Vasileva, D. Jovevski and V. Trajkovik. 2015. Impact of satisfaction, personality and learning style on educational outcomes in a blended learning environment. Learning and Individual Differences 38: 127-135. www.elsevier.com (Accessed 26 November 2015).

Vorhaus, J. 2010. Learning styles in vocational education and training. In International Encyclopedia of Education, ed. P. Penelope, B. Eva, M. Barry, 376-382. Elsevier, Oxford, quoted in Alkhasawneh, E. 2013. Using VARK to assess changes in learning preferences of nursing students at a public university in Jordan: Implications for teaching. Nurse Education Today 33: 1546-1549. www.elsevier.com

Williams, B., T. Brown and J. Etherington. 2013. Learning style preferences of undergraduate pharmacy students. Currents in Pharmacy Teaching and Learning 5: 110-119, quoted in Gohar, M. J. and N. Sadeghi. 2015. The impact of learning style preferences on foreign language achievement: A case study of Iranian EFL students. Procedia - Social and Behavioral Sciences 171: 754-764. www.sciencedirect.com

Wright, S. L., M. J. Duncan and M. Savin-Baden. 2015. Student perceptions and experiences of problem-based learning in first year undergraduate sports therapy. Journal of Hospitality, Leisure, Sport and Tourism Education 17: 39-49. www.elsevier.com (Accessed 26 November 2015). 